\title{
İmam Hatip Öğrencilerinin Sosyal Medya Kullanımındaki Dini Eğilimleri
}

\author{
Religious Tendencies of Imam Hatip Students in the Use of Social Media \\ Hüseyin Kasım KOCA \\ Dr., Millî Eğitim Bakanlığı, Dr. Sadık Ahmet Mesleki Eğitim Merkezi \\ Dr., Ministry of National Education, Dr. Sadik Ahmet Vocational Training Center Secondary \\ School \\ Sivas, TURKEY \\ huseyinkkoca@hotmail.com \\ https://orcid.org/ 0000-0002-6732-7871 \\ Doi: 10.34085/buifd.1004453
}

\section{Bu Araştırma; Sivas Cumhuriyet Üniversitesi'nin 13/11/2020 tarih ve 49253 Sayılı Etik İzin Onayı İle Yapılmıştır.}

Öz

İnsan yaşamına birçok yönden yenilik getiren sosyal medya uygulamaları, her geçen gün kullanım alanlarını geliştirmektedir. Mesajlaşmadan alışverişe, görüntülü konuşmadan oyun oynamaya kadar birçok alanda hizmet veren bu uygulamalar, insanların dini içerikli paylaşım yapmalarına da olanak tanımaktadır. Birçok din mensubunun yaptığı gibi sayıları milyarı aşan Müslümanların da bu platformlarda inandıkları dine ilişkin paylaşımda bulunmaları gayet doğaldır. Aynı şekilde dini yönden geniş bir müfredata sahip olan İmam Hatip Ortaokulu ve İmam Hatip Lisesi'nde öğrenim gören öğrencilerin de sosyal medya uygulamalarına kayıtsız kalmayacağı söylenebilir. Bu öğrencilerin dini bilgi anlamında okulda elde ettikleri kazanımları kullandıkları sosyal medya mecralarında paylaşmaları, toplumun doğru dini bilgiye ulaşabilmesine vereceği katkı yönüyle oldukça önemlidir. Nicel araştırma yönteminin kullanıldığı araştırmada anket yöntemiyle elde edilen veriler betimsel ve ilişkisel analize tabi tutulmuştur. Araştırmada Sivas il merkezinde İmam Hatip Ortaokulu ve Liselerinde öğrenimlerine devam eden öğrencilerin sosyal medya kullanımındaki önceliklerinin ve bu kullanımlara dinin etkisinin incelenmesi hedeflemektedir. Veriler 2019-2020 eğitim öğretim yılında İmam Hatip Ortaokulu ve Liselerinde öğrenimlerine devam eden 300 öğrenciden elde edilmiştir.

Anahtar Kelimeler: Din Eğitimi, Sosyal Medya, İmam Hatip, Sivas.

Abstract

Social media applications, which bring innovations to human life in many ways, are improving their usage areas day by day. These applications, which serve in many areas from messaging to shopping, from video chat to playing games, also enable people to share religious content. It is quite natural for Muslims, whose number exceeds one billion, to share their religion on these platforms, like many members of religion. It is very important for these students to share the achievements they have obtained at school in terms of religious knowledge on the social media channels they use, in terms of contributing to the society's access to the right religious information. In the study, in which the quantitative research method was used, the data obtained by the scanning method were subjected to descriptive and relational analysis. In the research, it is aimed to examine the priorities of the students who continue their education in Imam Hatip Secondary School and High Schools in Sivas city center in the use of social media and the effect of religion on these uses. The data were obtained from 300 students continuing their education in Imam Hatip Secondary Schools and High Schools in the 2019-2020 academic year.

Keywords: Religious Education, Social Media, Imam Hatip, Sivas.

GİRiş

Bilgisayar teknolojisinin bulunmasından sonra iletişim uyduları ile gelişen teknolojinin birleşmesinden doğan yeni iletişim olgu ve süreci "Bilgi Çağı" olarak adlandırılmaktadır. ${ }^{1}$ Bu çağın en önemli aşamalarından birisi, internetin bulunmasıdır. İnternet kullanımı ile veriler küresel ölçekte kitlelere ulaşabilirken aynı zamanda insanlara iletişim ve bilgi noktasında eşsiz imkânlar sunmaktadır. İnternet, benzer ilgi alanlarına, değerlere veya hedeflere sahip insanların birbirleriyle ilişki kurmasının yollarını kolaylaştırarak her geçen gün daha fazla günlük yaşamın bir parçası haline

\footnotetext{
${ }^{1}$ Umut Davut Başoğlu- Şenol Yanar, "Üniversite Öğrencilerinin Sosyal Medya Kullanım Amaçları ve Alışkanlıklarının Belirlenmesi", Kilis 7 Aralı Üniversitesi Beden Eğitimi ve Spor Bilimleri Dergisi 1 / 2 (Aralık 2017), 7.
} 
gelmektedir. ${ }^{2}$ Artık internet üzerinde tam sayısını kimsenin bilmediği kadar blog, yüz milyonlarla ifade edilen video ve resim içeriği, yine bir o kadar gerçek ve takma adlarla oluşturulmuş kullanıcı profilleri mevcuttur. ${ }^{3}$

Kullanılmaya başlandığı ilk dönemde haber takibi ve mesajlaşma gibi basit denebilecek bazı özellikleriyle insan hayatına giren internet, günümüzde alışverişten film izlemeye, sağlık desteğinden görüntülü konuşmaya kadar birçok alanda yenilik getirmektedir. Bu yeniliklerden birisi de sosyal medya uygulamalarıdır. İletişim teknolojilerinde yaşanan gelişmelerle birlikte her geçen gün kullanım alanlarını geliştiren bu platformlar, insan yaşamını da önemli ölçüde etkilemektedir.

Sosyal medya, kullanıcının kendi oluşturduğu içeriği diğer kullanıcılarla paylaşmasına izin veren uygulamaların genel adıdır. ${ }^{4}$ Bu uygulamalar her yaştan insanın birbirleriyle iletişim kurması, görüş ve deneyimlerini paylaşması, bilgi edinmesi ve boş vakitlerini değerlendirmesi gibi daha birçok amaçla kullanılabilmektedir. ${ }^{5}$ We Are Social Araştırma Merkezi'nin 2021 yılı verilerine göre insanlık nüfusunun $\% 45$ 'ine tekabül eden 4,2 milyarlık kısmı aktif sosyal medya kullanıcısıdır. Türkiye'de ise 54 milyon aktif sosyal medya kullanıcısı bulunmaktadır. ${ }^{6}$ Türkiye nüfusunun yaklaşık üçte ikisinin sosyal medyayı aktif olarak kullanması, araştırmacıların bu alan üzerinde araştırmalar yapmasını gerekli kılmaktadır. Etkileşim, sosyalleşme ve eğlencenin yanında birçok konuda anlık iletişim imkânı sunan ${ }^{7}$ sosyal medya, modern insan için bir ihtiyaç halini almıştır. Bu durumun oluşmasında, kişilerin istedikleri zaman ve mekânda aktif olmaları ve dilediği paylaşımı yaparak birçok kişiye aynı anda istediği iletiyi ulaştırabilmesinin ${ }^{8}$ de etkisi bulunmaktadır.

Orta Doğu Teknik Üniversitesi (ODTÜ) ve Bilgi Teknolojileri ve İletişim Kurumu Telekomünikasyon İletişim Başkanlığı'nın destekleriyle gerçekleştirilen ve 9-16 yaş grubu 524 birey ile hanelerde yüz yüze görüşmeler yapılarak ve bu gençlerin sosyal paylaşım sitelerini kullanma alışkanlıkları ortaya konmuştur. Buna göre; bireylerin yaklaşı \% $70^{\prime}$ i günde en az bir kere interneti kullanırken, \%66'sı günde en az bir kere sosyal ağları kullanmakta ve burada ortalama 72 dakika zaman harcamaktadırlar. Gençlerin $\% 60^{\prime} 1$ sosyal ağların ders çalışma sürelerine olumsuz etkisi olduğunu söylerken yaklaşık \%25'i sosyal medya yüzünden arkadaşlarına ve ailelerine daha az zaman ayırdıklarını ifade etmişlerdir. ${ }^{9} \mathrm{Bu}$ noktada sosyal medya uygulamaları kendilerini güncel tutarak kullanımlarını artırmaya devam ettikçe, günümüz öğrencilerinin hayatındaki yerinin sürekli artmaya devam edeceği bilinmelidir. ${ }^{10}$ Bu sebeple başta eğitimciler olmak üzere toplumda sözü geçen tüm çevrelerin özellikle gençler arasında giderek artan sosyal medya bağımlılığı konusunda halkı bilinçlendirmesi ve bu uygulamaların doğru kullanımı konusunda farkındalık oluşturması gereklidir. Benzer şekilde Millî Eğitim Bakanlığı'nın 2007 yılından beri 7. ve 8. sınıflarda seçmeli olarak okuttuğu Medya Okuryazarlığı dersinin diğer sinıflarda da müfredata eklemesi gayet yerinde bir adım olacaktır.

Sosyal medya; sosyal, kültürel ve ekonomik yaşamı olduğu kadar dini alanı da etkilemektedir. Din, doğası gereği insan olan her yerde kendisini gösteren bir yapıya sahiptir. Bu anlamda inanan insanlar için önemli bir değer olan dinin inananları tarafından sosyal medya mecralarında yer almasının kaçınılmaz olduğu söylenebilir. Nitekim yapılan araştırmalarda her geçen gün genelde

\footnotetext{
${ }^{2}$ Giordano Carolyn - Giordano, Christine, "Health Professions Students' Use of Social Media", Journal Allied Health 40/2 (Haziran 2011), 78.

${ }^{3}$ Haluk Tanrıverdi- Sena Sağır, "Lise Öğrencilerinin Sosyal Ağ Kullanım Amaçlarının ve Sosyal Ağları Benimseme Düzeylerinin Öğrenci Başarısına Etkisi", Adıyaman Üniversitesi Sosyal Bilimler Enstitüsü Dergisi /18 (Aralık 2014), 777.

${ }^{4}$ Yumi Lim vd., "The impact of social media on destination branding: Consumer-Generated Videos Versus Destination

Marketer-Generated Videos", Journal of Vacation Marketing 18/3 (Eylül 2012), 199.

${ }^{5}$ Esma Gülşah Taner- Süleyman Yükçü, "Sosyal Medya Ekonomisinde Maliyet ve Fayda Analizi", Atatürk Üniversitesi İktisadi ve İdari Bilimler Dergisi 33 / 4 (Ekim 2019), 1382.

${ }^{6}$ We Are Social, Türkiye'de Aktif Sosyal Medya Kullanıcısı (Şubat 2021).

${ }^{7}$ Deniz Kılıç- Kenan Ateşgöz. “İşitme Engelli Öğrencilerin Sosyal Medya Ağ Sitelerini Kullanım Motivasyonları”. İnif E- Dergi 3

/ 2 (Kasım 2018), 76.

${ }^{8}$ Hasan Çiftçi, “Üniversite Öğrencilerinde Sosyal Medya Bağımlılı̆̆”, Manas Sosyal Araştırmalar Dergisi 7/4 (Ekim 2018$), 420$.

${ }_{9}$ Türkiye İletişim Kurulu Başkanlığı. “Çocukların Sosyal Paylaşım Sitelerini Kullanım Alışkanlıkları Araştırması Raporu_(Ocak 2019)

10 Qingya Wang vd., "The Effects of Social Media on College Students", Scholars Archive, 1/5 (Kasım 2011), 8.
} 
internetin, özelde de sosyal medyanın toplumun tüm kesimleriyle birlikte dindar kesimlerde de

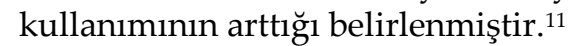

Millî Eğitim Bakanlığı verilerine göre 2021 yılı itibariyle bir milyon üç yüz elli bin öğrenci İmam Hatip okullarında öğrenim görmektedir. ${ }^{12}$ İmam Hatip okullarında öğrenim gören öğrencilerin dini yönden yoğun bir müfredatla öğrenim gördüğü bilinmektedir. Her sınıf seviyesinde değişmekle birlikte Tefsir, Hadis, Siyer, Temel Dini Bilgiler, Kelam, Dinler Tarihi, Kur'ân-1 Kerîm gibi dersler gören imam hatip öğrencilerine öğrendiklerini paylaşma noktasında sosyal medya önemli bir zemin oluşturmaktadır. Bu noktada İmam Hatip öğrencilerinin sosyal medya paylaşımlarındaki önceliklerini tespit etmek ve bu öğrencilerin okullarında Kur'ân-1 Kerîm ve sahih sünnete dayalı olarak edindikleri dini bilgilerin onların sosyal medya kullanımlarına etkisini belirlemek araştırmanın problemini oluşturmaktadır.

Araştırma için 13/11/2020 tarihide Cumhuriyet Üniversitesi Hukuk Müşavirliğinden E-0263016050.06.04-49253 sayısıyla etik kurul izni alınmıştır. Araştırmada imam hatip okullarında dini yönden geniş bir müfredatla öğrenim gören öğrencilerin sosyal medya kullanımları incelenmiştir. Çalışmanın bu noktada İmam Hatip öğrencilerinin sosyal medyadaki önceliklerinin belirlenmesine ve bu sayede ilerleyen dönemlerde yenilenmesi muhtemel İmam Hatip meslek dersleri öğretim programlarına katkı sağlaması düşünülmektedir.

\section{Sosyal Medya ve Din}

İçerisinde bulunulan zaman diliminde teknolojinin oldukça hızlı bir gelişim seyri izlediği gözlemlenebilmektedir. Teknolojik yeni ürünler ve buna bağlı diğer alanlar artık gündelik yaşamın olmazsa olmazı durumuna gelmiştir. ${ }^{13}$ Bu öyle bir hâl almıştır ki son teknolojiye sahip ürünler birkaç sene içerisinde demode olabilmekte ve insanlarda yenisini edinme ihtiyacı oluşturabilmektedir. $\mathrm{Bu}$ yenileşme akımına öncülük eden platformlardan birisi de sosyal medya uygulamalarıdır.

Sosyal medya, kişiler arasındaki etkileşimi destekleyen, bireylere bilgi, düşünce ve görsel birçok şeyi paylaşma imkânı veren ve herkesin kendi kişisel profilini ve iletişim kurmak istediği arkadaş listesini oluşturmaya olanak tanıyan web tabanlı ortamlar olarak tanımlanabilir. ${ }^{14}$ Sosyal ağlar, genellikle ortak özelliklerden (bölge, meslek, okul, akraba vb.) hareketle oluşturulan ve çok sayıda üyesi bulunan ortamlar olmaları nedeniyle popüler olmuş, insanların birbirleri ile bağlantı kurmasında en çok tercih edilen iletişim biçimi olarak hızla yaygınlaşmıştır. ${ }^{15} \mathrm{Bu}$ noktada sosyal medya, giderek ekonomik, toplumsal ve siyasal bir güç niteliği kazanmaktadır. ${ }^{16}$ Amerika merkezli Global Digital Statistics kurumunu vermiş olduğu internet ve sosyal medya kullanım verilerine göre dünya nüfusunun \%59,5'i olan 4,6 milyar insan interneti aktif olarak kullanırken, 4,2 milyarlık kismı ise sosyal medya kullanmaktadır ${ }^{17} \mathrm{Bu}$ da dünya nüfusunun yarısından fazlasının sosyal medya kullandığını göstermektedir.

Günümüz iletişiminin en gözde araçlarından olan sosyal medya, zaman ve mekân sınırlaması olmadan kullanıcılarına hizmet sunmaktadır. Sosyal medyanın giderek küresel bir güce ulaşması, teknolojik alanda meydana gelen birçok yeniliğin kaçınılmaz sonucudur. Sosyal medyanın sürekli olarak etki alanını attırmasının altında yatan bir diğer neden de her geçen gün yeni yazılımların

\footnotetext{
${ }^{11}$ Bkz: Nihat Oyman, "Sosyal Medya Dindarlı̆̆", Kahramanmaraş Sütçü İmam Üniversitesi İlahiyat Fakültesi Dergisi / 28 (Aralık 2016), 126.; Sefer Yavuz, “İlahiyat Fakültesi Öğrencilerinin Sosyal Medya Dini Paylaşım Tutumları”, Dini Araştırmalar, 23 (57) , (Haziran 2020), 62 .; Elif Kocagöz vd., "Mahremiyet ve Dindarlık Perspektifinden Sosyal Medya Platformlarında Görsel Paylaşımının İncelenmesi: Ksü Öğrencileri Üzerinde Bir Uygulama", Kahramanmaraş Sütçü İmam Üniversitesi İktisadi ve İdari Bilimler Fakültesi Dergisi 10 / 1 (Haziran 2020), 84.; Hüsnü Bodur - Sezai Korkmaz, "İlahiyat Öğrencilerinde Sosyal Medya Kullanımı ve Dindarlık İlişkisi". Kahramanmaraş Sütçü İmam Üniversitesi İlahiyat Fakültesi Dergisi / 30 (Aralık 2017), 332.; Yunus Ergen, "Sanala Veda: Sosyal Medya ve Dönüşen Dindarlık", Medya ve Din Araştırmaları Dergisi 3 / 2 (Aralık 2020), 287.; Hasan Meydan vd., "Sosyal Medya ve Gençlik Değerleri: Zonguldak'ta Liselerde Öğrenim Gören Gençler Üzerine Bir İnceleme”, Türkiye Din Ĕ̆itimi Araştırmaları Dergisi, 7, 127.

12 Millî Eğitim Bakanlığı (MEB), İmam Hatip Okullarında Öğrenim Gören Öğrenci Sayıları (Şubat 2021).

${ }^{13}$ Deniz Yengin, Yeni Medya ve ... (İstanbul: Anahtar Kitaplar Yayınevi, 2012), 11.

${ }_{14}$ Sercan Kural vd., "Investigation Of The Relationship Between Social Media Usage Habits And Personality Characteristics Of Bartın University Pes Students", International Journal Of Sport Culture And Science 4 / Special Issue 3 (Aralık 2016), 872.

${ }^{15}$ Mine Bayar- Şama Erdoğan, "Sosyal Ağların Sınıf İçi Değer Yapısı ve İstenmeyen Öğrenci Davranışları Üzerine Bir Derleme Çalışması", Çă̆daş Yönetim Bilimleri Dergisi 6 / 1 (Nisan 2019), 55.

${ }^{16}$ Güliz Uluç, Küreselleşen Medya: İktidar ve Mücadele Alanı, (İstanbul, Anahtar Kitaplar Yayınevi, 2003$), 11$.

17 We Are Social, Dünyadaki Aktif Sosyal Medya Kullanıcısı (Şubat 2021).
} 
ortaya çıkması ve bu sayede de değişen teknolojiye ve insanın değişim arzusuna ayak uydurarak hep "yeni" kalmasıdır. ${ }^{18}$ Bu noktada hemen her yerde ve her zaman ulaşılabilen bu platformlar çocuk, genç, yaşlı, kadın, erkek, zengin, fakir, dindar veya herhangi bir dine inanmayan fark etmeksizin toplumun tüm kesimleri tarafından kabul görerek kullanım alanı bulabilmektedir.

Sosyal medyada bireyler, profillerini olduğu gibi değil de olmak istedikleri gibi oluşturulabilmektedir. ${ }^{19} \mathrm{Bu}$ da sosyal ağların sanal bir yönü olduğunu ortaya koymaktadır. $\mathrm{Bu}$ ortamların herhangi bir alanda eğitim, bilgi, başarı ve yetenek sahibi olmayan insanlara da söz söyleme hakkı tanıması ve düşüncelerini her yerde herkese kolaylıkla aktarabilme fırsatı sunması, milyonlarca insanın bu ağlara bağlı kalmasına sebep olmaktadır. Her türlü bilgi, duygu ve düşüncenin kolaylıkla paylaşılmasına imkân veren bu platformlar, hiçbir kritere bağlı kalmaksızın dini paylaşımların da birçok insana ulaşmasına zemin oluşturabilmektedir.

Genel olarak dinin, özelde ise İslâm'ın yaşamın her alanında kendini gösterme gibi bir doğası vardır..$^{20} \mathrm{Bu}$ anlamda sosyal medya gibi milyonlarca insanın bulunduğu bir alanda, İslâm dinine dair paylaşımların yapılması son derece doğaldır. Günümüz iletişim teknolojilerinin insan hayatına sunduğu bu platformlar insanlara daha önce hiç olmadığı kadar kolaylıkla mesajlarını birçok insana ulaştırma imkânı sunmaktadır. Bu yönüyle Müslümanlar oturdukları yerden diledikleri insana, diledikleri bilgiyi, görüntüyü, videoyu gönderebilmekte; İslâm'ın emir, yasak ve tavsiyelerini bildirebilmektedir.

İslam dininin yayılması ve öğretilerinin hayat bulması noktasında tebliğ faaliyeti hayati bir öneme sahiptir. İslam'ın ilk yıllarından günümüze kadar birçok Müslüman, İslam'ı başka insanlara tanıtmak için tebliğ yapmayı kişisel bir görev olarak kabul etmiş ve uygun ortamlarda bu sorumluluğu hem amelî hem de sözlü olarak yerine getirmeye çalışmışır. ${ }^{21}$ Bu anlamda Kur'ân-1 Kerîm ve sahih sünnete vâkıf, İslâm'ın özünü kavramış, insan psikolojisini ve sosyolojiyi bilen, liyakatli insanların sosyal medya platformlarını boş bırakmaması son derece önemlidir.

\section{Yöntem}

Nicel araştırma yönteminin tercih edildiği araştırmada din ve sosyal medya gibi kapsamı oldukça geniş olan bir alanda dini ağırlıklı eğitim alan imam hatip öğrencilerinin sosyal medya kullanımlarındaki dini eğilimleri belirlenmeye çalışılmıştır. Araştırmada anket yöntemiyle elde edilen veriler betimsel ve ilişkisel analize tabi tutulmuştur.

Çalışmada, 11- 18 yaş arasındaki İmam Hatip Ortaokulu ve Lisesi'nde öğrenim görmekte olan öğrencilerin sosyal medya kullanımlarındaki üyeliklerinde, paylaşımlarında ve beğenilerinde dinin etkisi tespit edilmeye çalışılmıştır.

Çalışmanın hipotezi şu şekildedir.

İmam hatip öğrencilerinin sosyal medya üyeliklerinde, paylaşımlarında ve beğenilerinde dinin etkisi fazladir.

\subsection{Evren Örneklem}

Araştırmanın evreni 2019-2020 eğitim öğretim yılında İmam Hatip okullarında öğrenim görmekte olan öğrencilerdir. Örneklem alanı ise Mustafa Tâki İmam Hatip Ortaokulu, Sivas Anadolu İmam Hatip Lisesi ve Asım Şahin Kız Anadolu İmam Hatip Lisesi'nde öğrenimlerine devam eden öğrenciler arasından belirlenmiştir. Araştırmaya toplam 300 öğrenci katılım sağlamıştır. Katılımcıların 157 ‘si kız 143 'ü erkektir.

Araştırmaya katılan öğrencilerin \%23,8'i 11-15 yaş aralığındadır. Katılımcıların \%45,6'sı ise 16-17 yaş seviyesindeki öğrencilerden oluşmaktadır. 18 yaşında olan katılımcıların oranı ise \%30,6'dır. Araştırmanın \%76,2'sinin yaşça ileri seviyede olan öğrencilerle yapılmasının sebebi ise öğrencilerin artık bu yaşlarda sosyal medyayı aktif olarak kullanabileceğinin düşünülmesidir.

\subsection{Verilerin Toplanması}

Araştırma verileri araştırmacı tarafından imam hatip okullarında öğrenim gören öğrencilerden gönüllülük ve doğruluk esasına dayalı olarak toplanmıştır. Araştırmadaki veriler anket yöntemiyle

\footnotetext{
${ }^{18}$ Şerife Öztürk, "Sosyal Medyada Etik Sorunlar", Selçuk İletişim 9 / 1 (Ağustos 2015), 288.

${ }^{19}$ Gülsüm Çalışır, "Kişilerarası İletişimde Kullanılan Bir Araç Olarak Sosyal Medya: Gümüşhane Üniversitesi İletişim Fakültesi Öğrencilerine Yönelik Bir Araştırma", Humanities Sciences 10 / 3 (Temmuz 2015),119.

${ }^{20}$ Mehmet Akgül, Türkiye'de Din ve Değişim (İstanbul: Ötüken Yayınları, 2002), 34.

${ }^{21}$ Mustafa Çağrıcı, “Da'vet”, Türkiye Diyanet Vakfı İslâm Ansiklopedisi (Ankara: TDV Yayınları, 1994), 9/17.
} 
elde edilmiştir. $\mathrm{Bu}$ uygulama esnasında öğrencilerin cinsiyet ve yaş gibi kişisel bilgileri talep edildikten sonra sahip olunan sosyal medya hesapları ve bu hesaplardaki faaliyetleriyle alakalı bilgiler istenmiş ve bu faaliyetlerdeki dini eğilimleri tespit etmek amacıyla toplamda 10 soru yöneltilmiştir.

Sosyal bilimlerde alan araştırmasına dair literatürde veri oluşturmak için 200 katılımcının orta, 300 katılımcının iyi seviyede olduğu belirtilmektedir. ${ }^{22}$ Bu noktada anketin, uygulanan 300 imam hatip öğrencisiyle iyi bir seviye yakaladığı söylenebilir. Örneklem alanından anket yoluyla alınan verilerin yüzde ve frekansı belirlenmiş, tablolaştırma, yorumlama ve sonuç çıkarma yöntemleriyle de değerlendirmelerde bulunulmuştur.

\section{3. İmam Hatip Öğrencilerinin Sosyal Medya Kullanımlarındaki Dini Eğilimler Araştırması ve Yorumları}

\subsection{En Çok Kullanılan Sosyal Medya Hesapları}

İmam hatip öğrencilerinin en çok kullandığı sosyal medya hesapları arasında Facebook, İnstagram ve WhatsApp bulunmaktadır. Öğrencilerin bu uygulamalar içerisinde en sık kullandığı sosyal medya hesaplarının yüzdelik oranları ise tabloda gösterilmiştir.

Tablo 1: En Çok Kullanılan Sosyal Medya Hesapları

\begin{tabular}{cccc}
\hline Facebook & İnstagram & WhatsApp & Twitter \\
\hline 47 & 155 & 98 & 0 \\
$\% 15,6$ & $\% 51,6$ & $\% 32,6$ & \\
\hline
\end{tabular}

Araştırmanın örneklem grubunu oluşturan imam hatip öğrencilerinin en çok kullandığı sosyal medya hesapları incelendiğinde öğrencilerin yarısından biraz fazlasının İnstagram'ı daha fazla kullandığ konusu öğrenciler arasında İnstagram'ın oransal olarak bu kadar çok kullanılmasının sebebi, uygulamanın gençler arasında genel bir kabul görmesi ve İnstagram'ın fotoğraf ve video gibi görselliği ön planda tutan ve bu içeriği düzenlemeye olanak tanıyan bir yapıya sahip olması söylenebilir.

\subsection{Sosyal Medyayı Kullanma Sıklı̆̆ı}

Öğrencilerin sosyal medya bağımlılıklarını ortaya koyan sorulardan birisi olan günde ne kadar sosyal medyada kalırsınız sorusuna verilen cevaplar şu şekildedir:

Tablo 2: Sosyal Medyayı Kullanım Sıklı̆̆ı

\begin{tabular}{cccccc}
\hline $\begin{array}{l}\text { Günde Yarım } \\
\text { Saat ve Daha } \\
\text { Az }\end{array}$ & $\begin{array}{l}\text { Günde } \\
\text { Bir Saat }\end{array}$ & Günde İki Saat & Günde Üç Saat & $\begin{array}{l}\text { Günde Dört } \\
\text { Saat }\end{array}$ & $\begin{array}{l}\text { Günde Dört } \\
\text { Saatten } \\
\text { Fazla }\end{array}$ \\
\hline 81 & 67 & 50 & 19 & 19 & 64 \\
$\% 27$ & $\% 22,3$ & $\% 16,6$ & $\% 6,3$ & $\% 6,3$ & $\% 21,3$ \\
\hline
\end{tabular}

Genel olarak katılımcıların yaklaşık yarısı 1 saat ve daha az sosyal medyada kaldığını belirtirken, diğer yarısı ise 1 saatten fazla sosyal medyada vakit geçirdiğini ifade etmiştir. Günde 4 saatten fazla sosyal medya kullandığını söyleyenlerin oranı \%21,3 ile dikkat çekicidir. Oldukça uzun sayılabilecek bir süre sosyal medya kullanan bu grup öğrencilerin sosyal medya bağımlılığı konusunda aileleri ve öğretmenleri tarafından bilinçlendirilmeleri faydalı olabilecektir.

\footnotetext{
${ }^{22}$ Ezel Tavşancıl, Tutumların Ölçülmesi ve SPSS ile Veri Analizi (Ankara, Nobel Yayıncılık, 2014), 51.
} 


\subsection{Sosyal Medya Kullanma Amac1}

Kişiler, gerçek yaşamda beğenilme, muhatap bulma, sosyalleşme ve ifade özgürlüğü açısından birtakım sıkıntılar yaşayabilmekte, ancak sanal ortamlarda bu sıkıntılar en aza indirilebilmektedir. Bu tip durumlar kişilerin sosyal medyayı kullanım sürelerini artırarak bağımlılığa varan olumsuzluklara sebebiyet verebilmektedir. ${ }^{23}$ Bu noktada sosyal ağlar üç çeşit ihtiyacın karşılanması üzerinde etkilidir. Bunlar, hedonistik hazlar (zevk, fantezi ve kaçış), başarıya ilişkin hazlar ve sosyal hazlardır. ${ }^{24} \mathrm{Bu}$ hazları sürekli olarak doyurmak isteyen bireyler yaşadıkları her anı paylaşmak durumunda kalabilmektedir. Arkadaşlarıyla veya ailesiyle beraberken sosyal medyaya bağlı kalan bireyler özel hayat alanı dahil dini ve siyasi düşüncelerini, gezdiği yerleri, sahip olduğu eşyaları, yediği yemekleri vb. hayatın her alanını takipçilerine göstermekte tereddüt etmemektedir. Bu noktada imam hatip öğrencilerinin sosyal medyayı kullanma amaçları şu şekildedir:

Tablo 3: Sosyal Medyayı Kullanım Amacı

\begin{tabular}{|c|c|c|c|c|c|}
\hline Arkadaşlarımla & Dini & Haberleri & Dini & Oyun & Yeni \\
\hline İletişimde & Paylaşımlar & Takip & Paylaşımlar & Oynamak & Arkadaşlar \\
\hline Olmak & Yapmak & Etmek & Okumak & & Edinmek \\
\hline 234 & 3 & 44 & 0 & 15 & 4 \\
\hline$\% 78$ & $\% 1$ & $\% 14,6$ & $\% 0$ & $\% 5$ & $\% 1,3$ \\
\hline
\end{tabular}

Öğrencilerin sosyal medyayı kullanmadaki ana amacınız nedir sorusuna verdikleri cevaplara bakıldığında \%78 gibi büyük bir oranda arkadaş iletişimi öne çıkmaktadır. Arkadaşlarıyla bağını koparmak istemeyen bu grup öğrencilerin sosyalleşme ihtiyacı göz önüne alındığında ulaşılan sonuç anlamlıdır. Bu oranı haberleri takip için sosyal medya kullanıyorum diyen \%14,6'lık grup izlemektedir. Dini paylaşım yapmak için sosyal medya kullanan öğrenci oranı \%1 iken, dini paylaşımları okumak için sosyal medya kullanan öğrenci sayısı sıfırdır. Bu veriler imam hatip öğrencilerinin tamamına yakın kısmının sosyal medya kullanımlarında dini paylaşımlara öncelik vermediğini göstermektedir.

\subsection{Dini Paylaşım Yapma Sıklığı}

İmam hatip öğrencilerinin sosyal medya kullanımlarındaki dini paylaşım yapma durumunu gösterir tablo şu şekildedir:

Tablo 4: Dini Paylaşım Yapma Sıklı̆̆ı

\begin{tabular}{cccc}
\hline Her Gün & Haftada birkaç sefer & Çok Nadir & Hiç \\
\hline 12 & 110 & 93 & 85 \\
$\% 4$ & $\% 36,6$ & $\% 31$ & $\% 28,3$ \\
\hline
\end{tabular}

İmam hatip öğrencilerinin dini ağırlıklı bir eğitim aldığı göz önünde bulundurularak yöneltilen sosyal medyada dini paylaşım yapma sıklığı sorumuza verilen cevaplar oldukça dikkat çekicidir. Yaklaşık \%60'lık bir grup öğrenci çok nadir veya hiç cevabını verirken \%36'lık bir öğrenci grubu ise haftada birkaç sefer dini paylaşım yaptığını belirtmiştir. Yalnızca \%4'lük öğrenci grubu her gün dini paylaşım yaptığını ifade etmiştir. Bu da imam hatip öğrencilerinin büyük kısmının dini paylaşım yapma konusunda çok fazla istekli olmadığını göstermektedir.

Yaş itibariyle sosyalleşme ihtiyacının yoğun yaşandığı dönemde olan bu öğrencilerin sosyal medyayı iletişim amacıyla kullanmaları normal görülebilir. Ancak yoğun bir dini müfredata tabi tutulan bu öğrencilerin sosyal medya kullanımlarındaki öncelikler arasına dini paylaşımları neredeyse hiç almamaları oldukça dikkat çekici bir durumdur.

\subsection{Dini Paylaşım Yapılan Gruplara Üye Olma Durumu}

Öğrencilerin dini paylaşım yapılan gruplara üye olma durumlarını gösterir tablo şöyle oluşmuştur:

\footnotetext{
${ }^{23}$ Çiftçi, “Üniversite Öğrencilerinde Sosyal Medya Bağımlılığı”, 418.

${ }^{24}$ Ali Kuşcalı, "İslami İlimler Fakültesi Öğrencilerinin Sosyal Medya Kullanım Motivasyonlarının İncelenmesi”, Simetrik İletişim Araştırmaları Dergisi 1 / 2 (Temmuz 2019), 102.
} 
Tablo 5: Sosyal Medyada Dini Paylaşım Yapan Gruplara Üyelik

\begin{tabular}{ccccc}
\hline $\begin{array}{l}\text { Hayır } \\
\text { Değilim }\end{array}$ & $\mathbf{1 - 3}$ Gruba üyeyim & $\begin{array}{c}\text { 4-10 Gruba } \\
\text { Üyeyim }\end{array}$ & $\begin{array}{c}\mathbf{1 0 - 3 0 ~ G r u b a ~} \\
\text { Üyeyim }\end{array}$ & $\begin{array}{c}\text { 30 ve Üzeri Gruba } \\
\text { Üyeyim }\end{array}$ \\
\hline 169 & 114 & 12 & 0 & 5 \\
56,3 & $\% 38$ & $\% 4$ & $\% 0$ & $\% 1,6$ \\
\hline
\end{tabular}

Sosyal medyada dini paylaşım yapan gruplarda genel olarak ayet ve hadislerin kaynaklığında birçok dini meselenin konuşulduğu, tartışıldığı ve bu amaçla paylaşımlar yapıldığı görülmektedir. ${ }^{25}$ Bu yönüyle sosyal medyanın pek çok dini düşüncenin tanıtılması noktasında önemli bir alan olduğu söylenebilir.

Dini paylaşım yapan gruplara üyelik durumlarına bakıldığında $\% 56,3^{\prime} l u ̈ k$ bir grubun herhangi bir dini paylaşım grubuna üye olmadığı görülmektedir. \%38'lik bir öğrenci diliminin ise üçten az dini paylaşım grubuna üye olduğu tabloda gösterilen bir başka sonuçtur. Bu veriler 1şığında öğrencilerin çok büyük bir kısmının dini paylaşım gruplarına mesafeli durduğu söylenebilir. Araştırmaya katılan imam hatip öğrencilerinin yarısından fazlasının dini paylaşım yapan hiçbir gruba üye olmaması üzerinde düşünülmesi gereken bir konudur. Söz konusu öğrencilerin dini ağırlıklı eğitime tabi tutulması sonucunda oluştuğu tahmin edilen dini içerikten usanma duygusu, bu durumun bir sebebi olabilir. Diğer taraftan gençlik döneminde oluşan özgür bir şekilde hareket etme isteği de diğer bir neden olarak belirtilebilir.

\subsection{Dini Paylaşım Yapan Grupların Gönderilerini Beğenme Durumu}

İmam hatip öğrencilerinin sosyal medya kullanımlarındaki dini eğilimlerini belirleme amacıyla yöneltilen bir diğer soru da dini paylaşım yapan grupların gönderilerini beğenme durumudur. $\mathrm{Bu}$ soruya verilen cevaplar aşağıdaki tabloda gösterilmiştir.

Tablo 6: Dini Paylaşım Yapan Grupların Gönderilerini Beğenme Durumu

\begin{tabular}{ccc}
\hline Siklıkla & Bazen & Hiç \\
\hline 122 & 143 & 35 \\
$\% 40,6$ & $\% 47,6$ & $\% 11,6$ \\
\hline
\end{tabular}

Öğrencilerin \%40,6'sı sıklıkla bu dini paylaşımları beğenirken $\% 47,6^{\prime} l 1 \mathrm{k}$ bir dilim ise dini paylaşımları bazen beğendiğini bildirmiştir. \%11,6'lık bir öğrenci grubu ise dini paylaşım yapan gruplarını gönderilerini hiç beğenmediklerini ifade etmiştir.

Oldukça zengin bir içeriğe sahip olan sosyal medya uygulamaları birçok paylaşımı kullanıcısına sunmaktadır. Sadece sosyal medya arkadaşlarının paylaşımları değil onların beğendiği içerikler de kullanıcılara yansıyabilmektedir. Ayrıca sponsorlu paylaşımlar da kullanıcıların hesaplarında yer alabilmektedir. Bütün bu içerikler karşısında imam hatip öğrencilerinin hiçbir dini gruba üye olmasalar bile dini içeriklerle karşılaşması gayet doğaldır.

\subsection{Profil Resmini veya Kullanıcı Adını Dini Simge Olarak Kullanma Durumu}

Öğrencilerin profil resimlerini ve kullanıcı adlarını dini simge veya isim olarak kullanmalarının belirtildiği tablo şu şekildedir.

Tablo 7: Profil Resmini veya Kullanıcı Adını Dini Simge veya İsim Olarak Kullanma Durumu

\begin{tabular}{cc}
\hline Evet & Hayır \\
\hline 112 & 188 \\
$\% 37,3$ & $\% 62,7$ \\
\hline
\end{tabular}

\footnotetext{
${ }^{25}$ Muhammed Yamaç, "Sosyal Medyada Dini Topluluklar", Kocaeli İlahiyat Dergisi 4 / 1 (Haziran 2020),113.
} 
Profil resimleri ve adları kullanıcıların sosyal medya hesaplarındaki herkesin görebileceği şekilde konumlandırdığı içeriklerdir. Sosyal medya kullanıcılarının kendilerini tanıtma fonksiyonu yüklediği bu resimler ve isimler bu yönüyle kişinin sosyal medya hesabında oldukça önemli bir yere sahiptir.

Hesabınızdaki profil resminizi veya kullanıcı adınızı dini simge veya isim olarak kullandınız mı sorusuna öğrencilerin \%37,3'ü evet derken \%62,7'si hayır cevabını vermişlerdir. Yaklaşık her 3 öğrenciden ikisi profil resmini veya kullanıcı adını dini bir simge olarak kullanmayı tercih etmemesi öğrencilerin sosyal medyada dini içerik üretmekten kaçındıklarını ortaya koymaktadır.

\subsection{Sosyal Medyadaki Dindarlık Hissetme Durumu}

İmam hatip öğrencilerinin sosyal medya hesaplarında kendilerini dindar hissetme durumlarının ortaya konulduğu tablo şöyle oluşmuştur:

Tablo 8: Sosyal Medya Hesaplarmda Dindarlik Hissetme Durumu

\begin{tabular}{lcc}
\hline Sosyal Medyada Daha Dindarım & Gerçek Hayatta Daha Dindarım & İkisinde Aynıyım \\
\hline 15 & 97 & 188 \\
$\% 5$ & $\% 32,3$ & $\% 62,6$ \\
\hline
\end{tabular}

Sosyal medyadaki hayatıyla gerçek hayatı arasındaki dindarlık seviyesi karşılaştırıldı ı̆ında öğrencilerin yaklaşık üçte ikisinin her ikisinde de aynı olduğu görülmektedir. Gerçek hayatta daha dindarım diyenlerin oranı ise $\% 32,3^{\prime}$ tür. $\% 5^{\prime} l i k$ bir grup sosyal medyada daha dindar olduğunu belirtmiş̧ir. Bu verilerden hareketle öğrencilerin büyük çoğunluğunun kendilerini gerçek hayat ve sosyal medya hesaplarında aynı seviyede dindar hissettikleri söylenebilir. Ancak yaklaşık her üç öğrenciden birisinin sosyal medya ortamında gerçek hayata oranla kendisini daha az dindar görmesi oldukça düşündürücüdür.

\subsection{Sosyal Medyada Dini Tebliğ Yapma Durumu}

Öğrencilerin sosyal medya kullanımlarındaki dini eğilimlerinin tespit edilebilmesi amacıyla yöneltilen sosyal medya hesaplarını dini tebliğ amaçlı kullanma durumlarının ortaya konulduğu tablo şöyledir:

Tablo 9: Sosyal Medya Hesapların Dini Tebliğ Amaçlı Kullanma

\begin{tabular}{ccc}
\hline Sıklıkla & Bazen & Hiç \\
\hline 25 & 180 & 95 \\
$\% 8,3$ & $\% 60$ & $\% 31,6$ \\
\hline
\end{tabular}

Sosyal medyada sıklıkla dini tebliğ yapan öğrencilerin oranı $\% 8,3^{\prime}$ te kalmıştır. Geri kalan öğrencilerin \%60'ı bazen dini tebliğ yaptığını belirtirken, \%31,6'llk bir öğrenci grubu hiç dini tebliğ yapmadığını ifade etmiştir. Bu da öğrencilerin büyük bir kısmının sosyal medyada dini tebliği öncelemediği sonucunu ortaya koymaktadır.

Yapılan bir araştırmada dini tebliğini sosyal medya üzerinden gerçekleştiren dini grupların sayısının giderek arttığ1 ortaya konulmuştur. ${ }^{26} \mathrm{Bu}$ da sosyal medyanın her geçen gün sunduğu imkanlarla dini alana daha fazla yer açtığını göstermektedir

\subsection{Sosyal Medyadaki Dini Tartışmalara Katılma Durumu}

İmam hatip öğrencilerinin sosyal medya üzerinden yürütülen dini tartışmalara katılıp yorum yapma durumlarının gösterir tablo şu şekildedir:

Tablo 10: Sosyal Medya Üzerindeki Dini Tartışmalara Katılıp Yorum Yapma Durumu

\begin{tabular}{lcc}
\hline Siklıkla & Bazen & Hiç \\
\hline 31 & 110 & 159 \\
$\% 10,3$ & $\% 36,6$ & $\% 53$ \\
\hline
\end{tabular}

\footnotetext{
${ }^{26}$ Gamze Gezgincï -Şevki Işıklı, "Dindar Facebook Etkisi: Türk Kullanıcılar Üzerine Bir Analiz". Medya ve Din Araştırmaları Dergisi 1 / 1 (Haziran 2018), 129.
} 
Sosyal medya üzerinde yürütülen tartışmalara katılma oranları incelendiğinde imam hatip öğrencilerinin yarısından fazlasının bu tip tartışmalara katılmadıkları görülmektedir. Tabloda $\% 36,6^{\prime} l 1 k$ bir öğrenci grubunun bu tartışmalara bazen katıldığı görülebilmektedir. Öğrencilerin \%10,3'ü sıklıkla sosyal medyadaki dini tartışmalara katıldığı da araştırmada ortaya çıkan bir başka sonuçtur.

\section{SONUÇ}

İnsanlık tarihi boyunca iletişim, en temel ihtiyaçlardan birisi olmuştur. İçinde bulunulan çağın insanlığa sunduğu en büyük kolaylıklardan birisi de iletişimde yaşanan gelişmelerdir. Geleneksel medya denilen gazete, $t v$, radyo gibi haberleşme araçlarının birincil kaynak olma özelliğini her geçen gün çok yönlü ve interaktif iletişim imkânı da sunan sosyal medya uygulamaları almaktadır.

Sosyal medyanın kullanıldığı alanlardan birisi de dini tebliğdir. İnsanın yaratıcısı ve ebedi âlemle ilgili bilgilerinin yegâne kaynağını oluşturan dini yapı, sadece bireyin iç dünyasında kalarak kişisel bir alana hapsedilemez. Dinin doğasında insan olan hemen her yerde kendisini göstermesi ve her türlü platformda varlığını hissettirmesi bulunmaktadır. Milyonlarca insanın hemen her gün kullandığı sosyal medya platformlarında da dini yapının tezahürlerini görmek son derece doğaldır. Bu noktada inansın ya da inanmasın herkesin dine ilişkin düşüncelerini hiçbir sınırlama olmaksızın sosyal medya hesaplarında paylaşabilmesi ve takipçilerini dini yönden etkileyebilmesi mümkündür.

Bu noktada araştırmanın çerçevesi olarak belirlediğimiz imam hatip öğrencilerinin sosyal medya kullanımlarındaki dini eğilimlerinin tespit edilmesi amacıyla 300 öğrenciyle görüşme gerçekleştirilerek veriler elde edilmiştir. Elde edilen veriler neticesinde şu sonuç ve öneriler belirtilebilir:

İmam Hatip öğrencileri genel olarak sosyal medya kullanım süreleri bakımından ülke ortalamalarından kayda değer herhangi bir farklılık göstermemişlerdir.

Öğrencilerin kullandığı en popüler sosyal medya uygulaması \%61'lik seviyesiyle İnstagram olmuştur. Bu sonuçta İnstagram'ın fotoğraf ve video gibi görselliği ön planda tutan yapısının etkili olduğu söylenebilir.

Öğrencilerin sosyal medyayı kullanma amaçlarında önceliği arkadaşlarla iletişim kurmak almaktadır. Dini paylaşım yapma ve yapılan dini paylaşımları okuma amacıyla sosyal ağlara bağlanan öğrenci yok denecek kadar azdır (\%1). Oldukça dikkat çekici olan bu durum imam hatip öğrencilerinin sosyal medyayı dini tebliğ amacıyla kullanmadıklarını göstermektedir. Benzer şekilde Gezginci ve Işıklı'nın 2018 yılında yapmış olduğu bir araştırmada Facebook kullanıcıların \%67'sinin paylaşımlarında herhangi bir dini öğeye yer vermediği belirtilmiştir. ${ }^{27}$ Bodur ve Korkmaz tarafından yapılan araştırmada dindarlık ile sosyal medya arasında herhangi bir ilişkinin olmadığı ortaya konulmuştur. ${ }^{28}$ Yavuz tarafından ilahiyat öğrencileri üzerinde yapılan bir araştırmada öğrencilerin öğrenim gördüğü üniversitenin sosyal medyadaki dini paylaşım tutumları üzerinde anlamlı bir etkiye sahip olmadığı sonucuna ulaşılmıştır.29 Kayacı tarafından imam hatip öğrencileri arasında yapılan araştırmada öğrencilerin \%85,5'i sosyal medyayı dini içerik amacıyla kullanmadığ konulmuştur. ${ }^{30} \mathrm{Bu}$ noktada yapılan araştırma sonucunda ortaya çıkan verilerin literatürde var olan diğer çalışmalarla ortaya konan verilerle tutarlılık gösterdiği söylenebilir.

Araştırmada öğrencilerin dini paylaşım yapma sıklığı da beklentinin altında kalmıştır. Sadece \%4'lük bir öğrenci grubu düzenli dini paylaşım yapıyorum cevabını vermiştir. \%36'lık bir öğrenci grubu ara sıra dini paylaşım yaparken \%60'lık bir öğrenci grubu çok nadir veya hiç dini paylaşım yapmiyorum cevabını vermiştir.

Sosyal medya hesaplarını dini tebliğ amaçlı kullanma durumunda ise her üç öğrenciden birisi “hiç” cevabını verirken \%60'lık bir öğrenci grubu "bazen” cevabını vermiştir. Bu durum öğrencilerin genelinin sosyal medya kullanımlarında dini tebliğ gibi bir amacının olmadığını göstermektedir.

Elde edilen sonuçlar neticesinde imam hatip öğrencilerinin sosyal medyayı dini tebliğ aracı olarak kullanmadıkları görülmektedir. Dolayısıyla hipotezimiz yanlışlanmıştır.

\footnotetext{
${ }^{27}$ Gamze Gezgincï- Şevki Işıklı, "Dindar Facebook Etkisi: Türk Kullanıcılar Üzerine Bir Analiz", Medya ve Din Araştırmaları Dergisi 1 / 1 (Haziran 2018), 129.

${ }^{28}$ Bodur- Korkmaz, "İlahiyat Öğrencilerinde Sosyal Medya Kullanımı ve Dindarlık İlişkisi", 330.

${ }^{29}$ Yavuz, “İlahiyat Fakültesi Öğrencilerinin Sosyal Medya Dini Paylaşım Tutumları”, 62.

30 Eyyüp Kayacı, "İmam Hatip Lisesi Öğrencilerinin Sosyal Medyaya İlişkin Tutumlarının İncelenmesi", Trabzon İlahiyat Dergisi $8 / 1$ (Haziran 2021), 59.
} 


\section{KAYNAKÇA}

Akgül, Mehmet. Türkiye'de Din ve Değişim. İstanbul: Ötüken Yayınları, 2002.

Ankaralı, Handan. "Beyoğlu Anadolu İmam Hatip Lisesi Öğrencilerinde İnternet ve Sosyal Medya Bağımlılık Düzeyi, Başarı ile İlişkisi ve Bağımlılık Üzerine Etkili Faktörler". Kalemname 4 / 8 (Aralık 2019), 301-331.

Başoğlu, Umut Davut -Yanar Şenol. "Üniversite Öğrencilerinin Sosyal Medya Kullanım Amaçları ve Alışkanlıklarının Belirlenmesi". Kilis 7 Aralk Üniversitesi Beden Eğitimi ve Spor Bilimleri Dergisi 1 / 2 (Aralık 2017), 6-13.

Bayar, Mine- Şama Erdoğan. "Sosyal Ağların Sınıf İçi Değer Yapısı ve İstenmeyen Öğrenci Davranışları Üzerine Bir Derleme Çalışması". Çağdaş Yönetim Bilimleri Dergisi 6 / 1 (Nisan 2019), 5470.

Bodur, Hüsnü- Korkmaz, Sezai. "İlahiyat Öğrencilerinde Sosyal Medya Kullanımı ve Dindarlık İlişkisi". Kahramanmaraş Sütçü İmam Üniversitesi İlahiyat Fakültesi Dergisi / 30 (Aralık 2017), 329-351.

Buhâri Ebû Abdillâh Muhammed b. İsmail el-Câmi 'u'ṣ-șahîḥ̣, nşr. Muhammed Züheyr b. Nasr (b.y.: Dâru Tavki'n-Necât, 1422/2001), “Cihad”,4 (No. 3468).

Carolyn Giordano- Giordano Christine. "Health Professions Students' Use of Social Media”. Journal of Allied Health 40/2 (Haziran 2011), 78-81.

Çağrıcı, Mustafa. "Da'vet", Türkiye Diyanet Vakfı İslâm Ansiklopedisi, 9/17. Ankara: TDV Yayınları, 1994.

Çalışır, Gülsüm. "Kişilerarası İletişimde Kullanılan Bir Araç Olarak Sosyal Medya: Gümüşhane Üniversitesi İletişim Fakültesi Öğrencilerine Yönelik Bir Araştırma". Humanities Sciences 10 / 3 (Temmuz 2015),115-144.

Çiftçi, Hasan. "Üniversite Öğrencilerinde Sosyal Medya Bağımlılığı”. Manas Sosyal Araştırmalar Dergisi 7/4 (Ekim 2018), 417-434.

Demir, Ümit. “Sosyal Medya Kullanımı ve Aile İletişimi: Çanakkale'de Lise Öğrencileri Üzerine Bir Araştırma". Selçuk İletişim 9/2 (Ocak 2016), 27-50. https://doi.org/10.18094/si.99029

Ergen, Yunus. "Sanala Veda: Sosyal Medya ve Dönüşen Dindarlık". Medya ve Din Araştırmaları Dergisi $3 / 2$ (Aralık 2020), 285-291.

Gezginci, Gamze- Işıklı, Şevki. "Dindar Facebook Etkisi: Türk Kullanıcılar Üzerine Bir Analiz". Medya ve Din Araştırmaları Dergisi 1 / 1 (Haziran 2018), 111-133.

Gülşah, Taner Esma- Yükçü, Süleyman. "Sosyal Medya Ekonomisinde Maliyet ve Fayda Analizi". Atatürk Üniversitesi İktisadi ve İdari Bilimler Dergisi 33 / 4 (Ekim 2019), 1381-1393.

Kayacı, Eyyüp. "İmam Hatip Lisesi Öğrencilerinin Sosyal Medyaya İlişkin Tutumlarının İncelenmesi". Trabzon İlahiyat Dergisi 8 / 1 (Haziran 2021), 39-74.

Kılıç, Deniz- Ateşgöz, Kenan. “İşitme Engelli Öğrencilerin Sosyal Medya A ̆̆ Sitelerini Kullanım Motivasyonları". Inif E- Dergi 3/2 (Kasım 2018), 75-88.

Kocagöz, Elif vd., "Mahremiyet ve Dindarlık Perspektifinden Sosyal Medya Platformlarında Görsel Paylaşımının İncelenmesi: Ksü Öğrencileri Üzerinde Bir Uygulama". Kahramanmaraş Sütçü İmam Üniversitesi İktisadi ve İdari Bilimler Fakültesi Dergisi 10 / 1 (Haziran 2020), 83-101.

Kur'ân Yolu, Erişim 3 Ocak 2020. https://kuran.diyanet.gov.tr

Kural, Sercan vd. "Investigation Of The Relationship Between Social Media Usage Habits And Personality Characteristics Of Bartın University Pes Students". International Journal Of Sport Culture And Science 4 / Special Issue 3 (Aralık 2016), 870-881.

Kuşcalı, Ali. "İslami İlimler Fakültesi Öğrencilerinin Sosyal Medya Kullanım Motivasyonlarının İncelenmesi". Simetrik İletişim Araştırmaları Dergisi 1 / 2 (Temmuz 2019), 100-110.

MEB, Millî Eğitim Bakanlığı, “Öğrenci Sayıları”. Erişim 10 Aralık 2020. 
http://sgb.meb.gov.tr/www/resmi-istatistikler/icerik/64

Meydan, Hasan vd. “Sosyal Medya ve Gençlik Değerleri: Zonguldak'ta Liselerde Öğrenim Gören Gençler Üzerine Bir İnceleme". Türkiye Din Eğitimi Araştırmaları Dergisi, 7, (Haziran 2019)125-143.

Oyman, Nihat. "Sosyal Medya Dindarlığı". Kahramanmaraş Sütçü İmam Üniversitesi İlahiyat Fakültesi Dergisi / 28 (Aralık 2016), 125-167.

Öztürk, Şerife, "Sosyal Medyada Etik Sorunlar", Selçuk İletişim 9 / 1 (Ağustos 2015), 287-311. https://doi.org/10.18094/si.57598

Tanrıverdi, Haluk- Sağır, Sena. "Lise Öğrencilerinin Sosyal Ağ Kullanım Amaçlarının ve Sosyal Ağları Benimseme Düzeylerinin Öğrenci Başarısına Etkisi". Adıyaman Üniversitesi Sosyal Bilimler Enstitüsü Dergisi / 18 (Aralık 2014), 775-822.

Tavşancıl, Ezel. Tutumların Ölçülmesi ve SPSS ile Veri Analizi. Ankara, Nobel Yayıncllık, 2014.

TİB, Türkiye İletişim Kurulu Başkanlığı. “Çocukların Sosyal Paylaşım Sitelerini Kullanım Alışkanlıkları Araştırması Raporu" Erişim 7 Ocak 2019.

https://docplayer.biz.tr/7446995-Cocuklarin-sosyal-paylasim-sitelerini-kullanim-aliskanliklariarastirmasi-raporu.html

TUIK, Türkiye İstatistik Kurumu, Erişim 15 Aralık 2020.

https://data.tuik.gov.tr/Bulten/Index?p=Hanehalki-Bilisim-Teknolojileri-(BT)-Kullanim-Arastirmasi2020-33679

Uluç, Güliz. Küreselleşen Medya: İktidar ve Mücadele Alanı. İstanbul: Anahtar Kitaplar Yayınevi, 2003.

Wang Qingya vd. "The Effects of Social Media on College Students". Scholars Archive, 1/5 (Kasım 2011), 1-12.

We are social, İnternet Kullanımı ve Sosyal Medya İstatistikleri, (Şubat 2021). https://wearesocial.com/uk/blog/2021/01/digital-2021-the-latest-insights-into-the-state-of-digital

Yamaç, Muhammed. "Sosyal Medyada Dini Topluluklar". Kocaeli İlahiyat Dergisi 4 / 1 (Haziran 2020), 101-122.

Yavuz, Sefer. "İlahiyat Fakültesi Öğrencilerinin Sosyal Medya Dini Paylaşım Tutumları". Dini Araştırmalar, 23 (57), (Haziran 2020), 37-64.

Yengin, Deniz. Yeni Medya ve...İstanbul: Anahtar Kitaplar Yayınevi, 2012.

Yumi Lim vd. "The impact of social media on destination branding: Consumer-generated videos versus destination marketer-generated videos". Journal of Vacation Marketing, 18/3 (Eylül 2012), 196-203. https://doi.org/10.1177/1356766712449366 